\title{
Prescription of medication before and after acute admission with nonspecific abdominal pain
}

\author{
Lena Boulakh ${ }^{1 *}$, Morten Lamberts ${ }^{2}$, Hanne Jørsboe ${ }^{1}$ \\ From 6th Danish Emergency Medicine Conference \\ Odense, Denmark. 20-21 November 2014
}

\begin{abstract}
Background
Abdominal pain is among the most common symptoms leading to referral to emergency departments in Denmark. Many of these patients are discharged without a specific diagnosis despite thorough work-up. We set out to assess the drugs prescribed to these patients in order to identify preconditions prior to admission based on their pharmaceutical treatment. This aims to generate hypotheses of admission causes derived from the drugs the patients have been prescribed since knowledge of drugs consumption patterns can improve treatment regimes.
\end{abstract}

\section{Methods}

National databases of patient registry (ICD-10 code R10) and prescriptions were used to identify use of medication in patients (age 16-100) admitted to hospital with abdominal pain in 2010. Exclusion criteria were surgical procedure work-up or diagnosis of gastrointestinal, renal, or gynecological disease one year prior to admission. Medical use at two time points was recorded: 90 days prior to admission and 90 days after discharge. New users were defined as no prescription of the same drug 90 days prior to admission. Particular attention was made to antibiotics, oral analgesics, and antacids. Data is presented as numbers and percentages.

\section{Results}

Nationwide, 12,081 patients were discharged with a ICD10 code of "acute abdominal pain" (64.4\% women, $35.6 \%$ men). Prior to admission, the percentage of patients using the symptomatic medications was: Oral analgesics $16.1 \%$ and antacids $21.2 \%$. After discharge there was a significant number of new users of: oral analgesics $48.5 \%$, especially NSAIDs and opioids, and antacids $47.2 \%$. Of special

\footnotetext{
* Correspondence: lenbo@regionsjaelland.dk

'Akutafdelingen, Nykøbing F. Sygehus, Nykøbing Falster, Denmark

Full list of author information is available at the end of the article
}

interest is that patients were prescribed antibiotics at both times; before $19.5 \%$ and after $63.8 \%(\mathrm{p}<0.05)$.

\section{Conclusion}

A substantial proportion of the patients collected a prescription of antibiotics, painkillers, and antacids. Further investigations of chart reviews and knowledge of the processes of clinical decision-making are needed to establish if it is an unrestricted prescription policy rather than an appropriate work-up. Additional studies of side effects and prescription profiles could provide insights to the symptoms leading to admission.

\section{Authors' details}

1Akutafdelingen, Nykøbing F. Sygehus, Nykøbing Falster, Denmark.

${ }^{2}$ Kardiologisk Afdeling, Gentofte Sygehus, Gentofte, Denmark.

Published: 16 July 2015

doi:10.1186/1757-7241-23-S1-A23

Cite this article as: Boulakh et al:: Prescription of medication before and after acute admission with nonspecific abdominal pain. Scandinavian Journal of Trauma, Resuscitation and Emergency Medicine 2015 23(Suppl 1): A23.

Submit your next manuscript to BioMed Central and take full advantage of:

- Convenient online submission

- Thorough peer review

- No space constraints or color figure charges

- Immediate publication on acceptance

- Inclusion in PubMed, CAS, Scopus and Google Scholar

- Research which is freely available for redistribution 